\title{
Mapping of Zones and Evacuation Routes for Disaster Overflow of the Krueng Langsa River
}

\author{
E N Lydia*, E Mutia \\ Civil Engineering Study Program, Faculty Engineering \\ Universitas Samudra \\ Banda Aceh, Indonesia \\ *ekamutia@unsam.ac.id
}

\begin{abstract}
The flooding of Krueng Langsa river occurs every year. The floodwaters submerged people's homes around the river. Every year SAR teams and communities have difficulty evacuating. This is due to the lack of flood zoning maps and evacuation routes. To reduce the risk of flooding overflowing in the Krueng Langsa river, evacuation route maps and zoning maps of flood hazard areas are needed., it is necessary to map evacuation routes in each hamlet as well as a zoning map of flood hazard areas. The purpose of this research is the availability of zoning maps and evacuation routes as one of the mitigations to reduce the risk of Krueng Langsa river overflow disaster. The data used is measurement data in the field and interviews. The data is analyzed using QGIS and CAD. The zoning mapping of insecurity levels is divided into 4 levels based on the weighting score of parameters that affect flooding. This map illustrates the direction of movement of each person to the gathering point and evacuation place. The evacuation route is chosen based on the distance to the collection point, the direction of the water flow, the height of the floodwater level, and the high ground level.
\end{abstract}

Keywords—mapping of zones, disaster overflow, flooding

\section{INTRODUCTION}

River flooding is one of the disasters that are always faced by people who live in the river. The flood can result in losses of both fatalities and property. To minimize the fatalities caused by the flood, mitigation planning such as effective evacuation route planning is required. The evacuation route will assist flood victims in finding a route to the evacuation site or a safer place quickly [1]. A disaster is an event or series that threatens and disrupts people's lives and livelihoods caused, either by natural factors and/or non-natural factors or human factors resulting in human casualties, environmental damage, property losses, and psychological impacts. Flooding is one of the natural disasters that occur due to the overflow of the volume of water that results in overflowing water to the mainland and an area [2].

The risk of flood losses occurring in urban areas, in general, is greater than that in rural areas, which is more at risk of differences in the level of community welfare facilities and population density factors [3].
Evacuation is a process that endangers people being moved from dangerous places to safety in an orderly manner to reduce vulnerability during this dangerous state. To mitigate the impact of disasters, proper evacuation planning is required [4]. The most important thing in the evacuation process is time and accessibility. For disaster risk reduction there are several ways, namely the provision of evacuation route maps, evacuation shelters, and signs [5].

Evacuation route is defined as the path that people must go through to escape from dangerous areas during emergencies The evacuation route is poured in a map containing information on the direction of the evacuation route, the location of the collection point, and the place of evacuation. The existence of evacuation maps, in the form of arrows pointing directions from a certain place to a predetermined safe assembly point [6]. Currently, the flood evacuation route map of Langsa city does not exist, especially in villages that often flood. In the event of flooding, some people self-evacuate to the main road, and others choose to remain in their homes and they will evacuate if the flood level covers most of their homes. This caused the SAR team to go down to evacuate the flooded houses to evacuate. They carried out the evacuation without using the route but only got information from the local community that had to be evacuated. Besides, they signify a place to make a path by tying a rope to a tree. It is inefficient and effective. Because it can cause risks for residents who are late to be evacuated because they are in a place that cannot be reached by the SAR team. Therefore, the map of the evacuation route is needed by the community and SAR team to evacuate when there is flooding Krueng Langsa river overflow.

\section{METHODS}

The research object is the villages affected by the Krueng Langsa River overflow disaster every year. The village is a Jawa village, Pondok Pabrik village, and Seulalah Baru Village located around the banks of Krueng Langsa river. However, not all villages were affected by the flooding, but only a few hamlets. In Jawa Village floods occurred in the hamlets of Jabel 1(KBC and Tanjung Putus) and Amalia, Seulalah Baru Village there were floods in the hamlets of Melati, Kenanga, 
and Dusun Cendana while in Pondok Pabrik village there was flooding in the villages of Nuri 1 and Nuri 2.

The purpose of this research was to find out the areas at risk of overflow disaster the Krueng Langsa river and determine effective evacuation routes in each village affected by the overflow disaster of the Krueng Langsa river. This research uses descriptive and surveys methods. Survey methods are used to obtain data from certain natural places. The use of this method is more effective because the data is obtained directly in the field [7]. The data used in this research used primary data derived from field measurements/surveys and interviews, while the secondary data was sourced from literature studies.

The activities in this research were carried out in three stages. The stages of research are as follows:

1. Preparation Stage, collect secondary data from various references and related agencies, in the form of Langsa City map, flood event data, high floodwater, and Qanun and Technical Materials from RTRW Langsa City

2. Survey stage consists of:

- Interviews were conducted with village officials and communities affected by the Krueng Langsa river overflow.

- Retrieval of coordinates using GPS consists of village boundary, flood level depth, and flood location

- Measuring roads, locations, and evacuation routes using Theodolite measuring instruments.

- Sketching measurements and photographing the necessary documentation.

3. Data Processing and Analysis Stage in the form of:

- Analysis of survey data calculation using excel assistance;

- Making zoning maps of flood-prone areas using QGIS software; Dan

- Making an evacuation route map using CAD software.

\section{RESULTS AND DISCUSSION}

\section{A. Zoning Maps of Flood Hazard Levels}

One of the efforts to minimize the negative impact of flood disasters with the availability of maps of flood-prone areas that can be used for planning, control, and early warning system. Mapping flood-prone areas can be identified quickly through geographic information systems using composed or overlay methods against flood parameters [8]. The map of the danger level of an overflow of the Krueng Langsa river is based on the level of vulnerability zoning. Zoning division based on the level of vulnerability that starts from the highest level of insecurity is medium, low, and safe. Figure 1 is a flood hazard zoning map of Krueng Langsa river overflow.

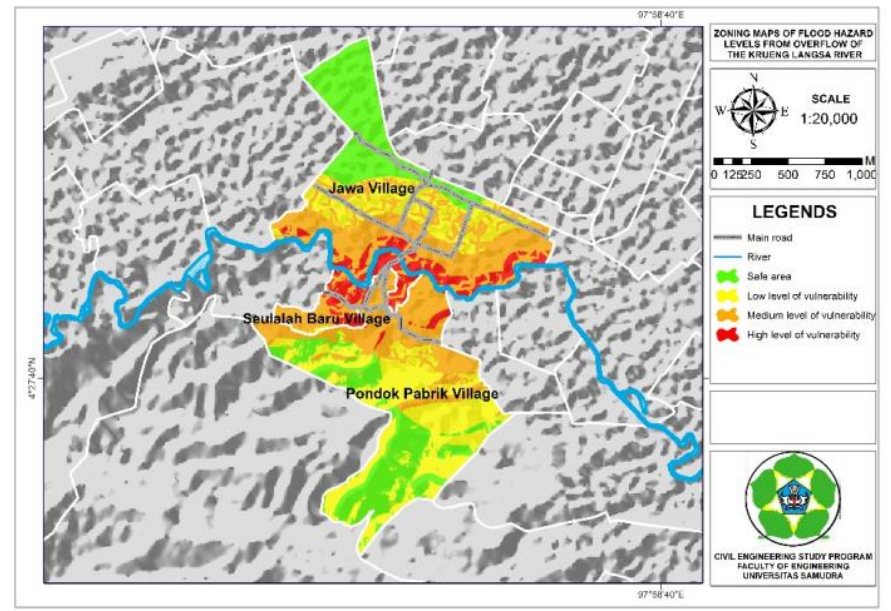

Fig. 1. Zoning maps of flood hazard levels from overflow of the Krueng Langsa river.

In figure 1 above can be seen in the red zone as an area with a high level of vulnerability and the area is directly adjacent to the river. As for the safe area away from the river and the height is higher than the riverbank. The zone is green. Determination of vulnerability level based on the weighting value of parameters that affect flood events such as rainfall, slope, infiltration, and land use. The higher the score, the greater the effect on flood events. The results of weighting or scoring for the level of insecurity caused by the Krueng Langsa river overflow flood can be seen in table 1 .

\section{TABLE I. RESULTS OF WEIGHTING/SCORING OF VULNERABILITY} LEVELS

\begin{tabular}{|l|l|}
\hline Vulnerability levels & \multicolumn{1}{c|}{ Score } \\
\hline Safe & $0.723-1.871$ \\
\hline Low & $>1.871-2.595$ \\
\hline Medium & $>2.595-3.318$ \\
\hline High & $>3.318$ \\
\hline
\end{tabular}

Based on table 1 can be seen the greater the score or weighting, the higher the level of vulnerability to flooding disasters overflow of Krueng Langsa river.

\section{B. Evacuation Route Map}

Based on figure 2,3 and 4. A flood hazard level zoning map from the Krueng Langsa River overflow was then created as an evacuation route map for areas with high vulnerability to flooding. An evacuation route map was created for villages whose hamlets were affected by flooding. 


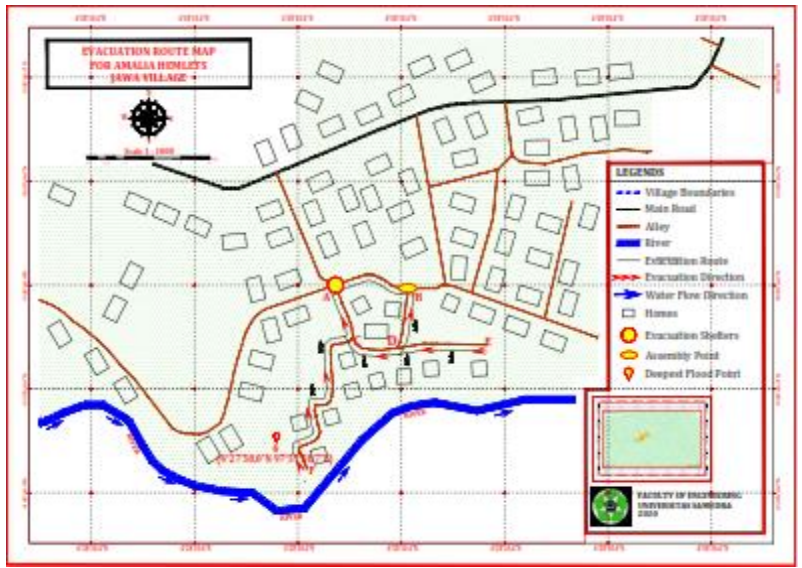

Fig. 2. Evacuation Route Map for Amalia Hamlet in Jawa Village.

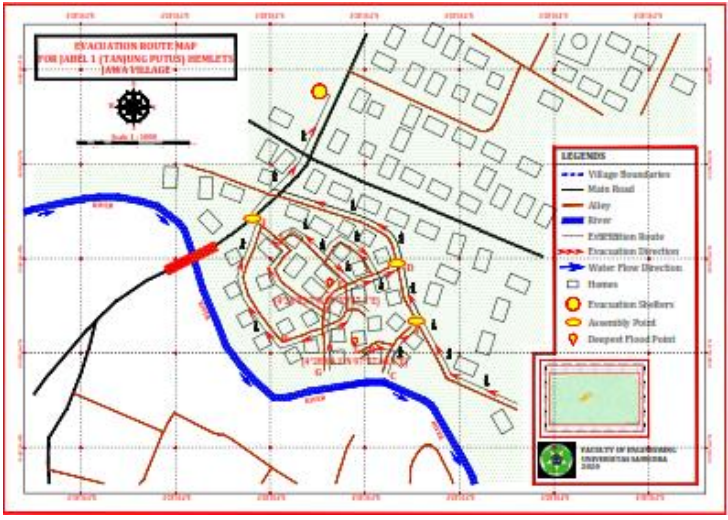

Fig. 3. Evacuation route map for Jabel 1 (Tanjung Putus) Hamlet in Jawa Village

The evacuation route in Java village is located in two different hamlets namely Amalia hamlet and Jabel 1 hamlet which is divided into the $\mathrm{KBC}$ area and Tanjung Putus area. In the $\mathrm{KBC}$ area and the Amalia hamlet, there are one assembly point and one evacuation shelter. The height of the floods is 1.9 meters and 1.5 meters. In the Tanjung Putus area, there are three assembly points and one evacuation shelter. The height of the flood is 1.6 meters.

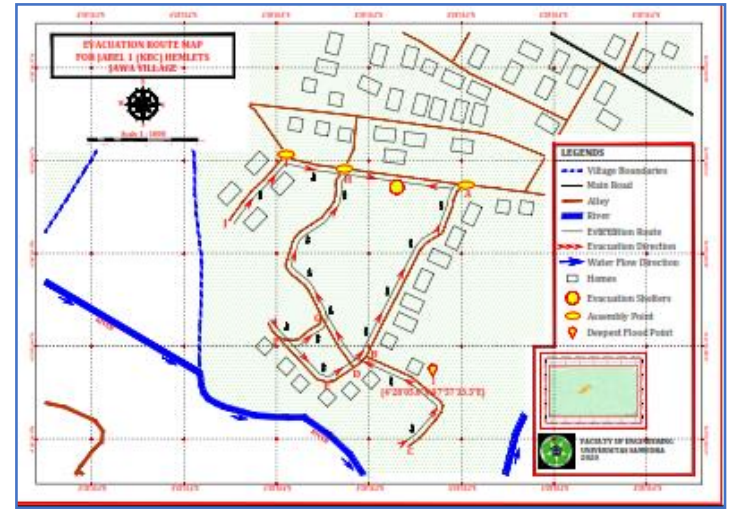

Fig. 4. Evacuation route map for Jabel 1 (KBC) Hamlet in Jawa Village

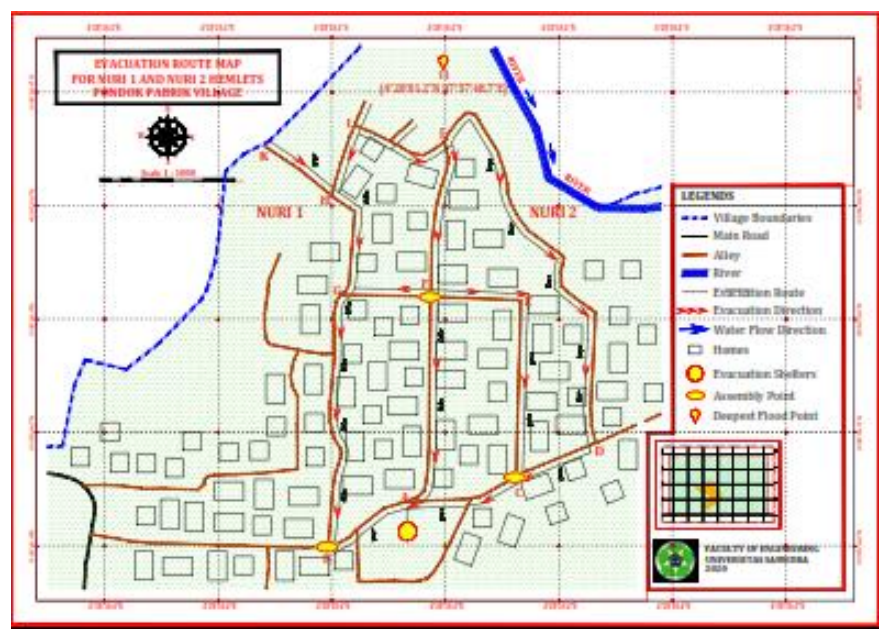

Fig. 5. Evacuation route map for Nuri 1 and Nuri 2 Hamlets in Pondok Pabrik Village.

In the figure 5 evacuation routes of Dusun Nuri 1 and Nuri 2 are made in one map. The floodwater level is 1.6 meters. Based on figure 5 there are three assembly points and one 
evacuation shelter. The evacuation site is located at Pondok Pabrik Village Office. Because the office has a large area of land, and some buildings can be used as temporary housing for flood victims.

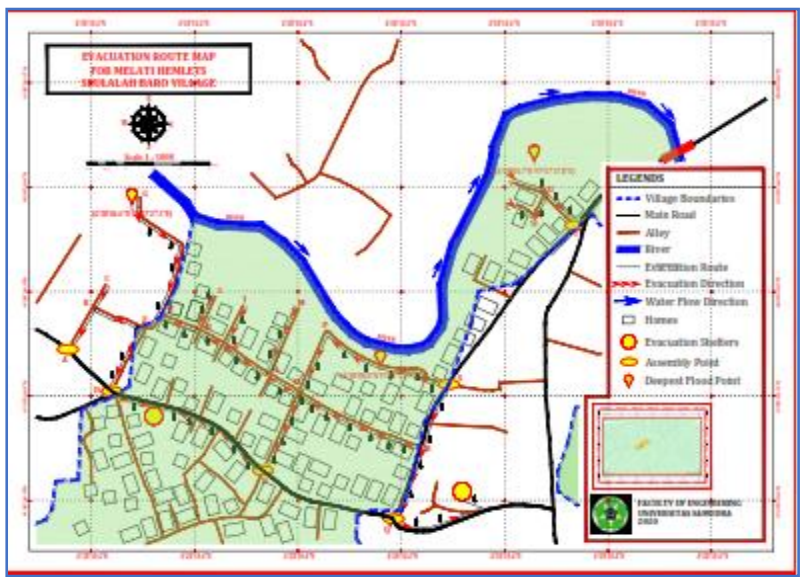

Fig. 6. Evacuation route map for Melati Hamlet in Seulalah Baru Village.

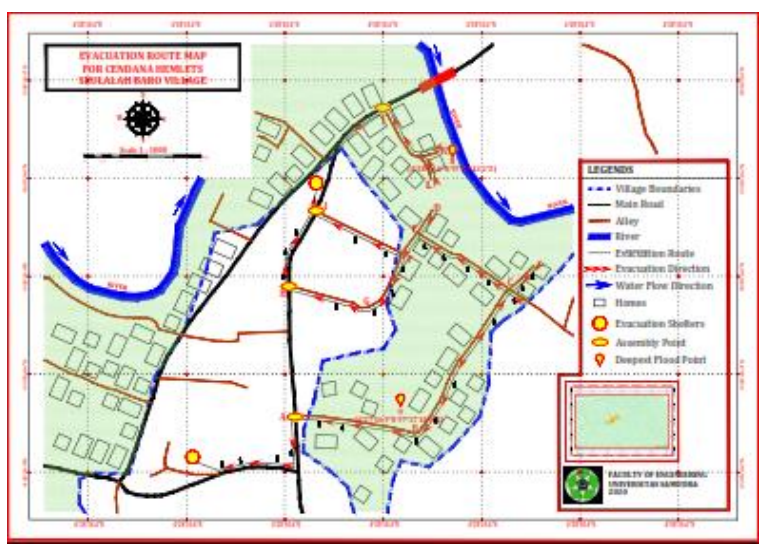

Fig. 7. Evacuation route map for Cendana Hamlet in Seulalah Baru Village.

Map of the evacuation route of Seulalah Baru village in figure 3 , describing the direction of movement of people in carrying out the evacuation. Each hamlet has an assembly point and evacuation shelter that is easy to reach. The depth of floodwater in Melati hamlet is 1.8 meters high, Cendana hamlet is $1.6 \mathrm{~m}$ high and Kenanga hamlet is 1 meter high.

The direction of the evacuation route in the hamlets of Jabel 1, Amalia, Cendana, Kenanga, Melati, Nuri 1, and Nuri 2 was made to stay away from the deepest points of flooding and the closest distance to the assembly point and evacuation shelter that is easily reached. The map of evacuation routes make it easier for people to evacuate independently to reduce the risk of flood disaster.

The selection of evacuation routes and evacuation sites meets the criteria. The road used as an evacuation route is a village road with a width of approximately $2.5 \mathrm{~m}$, making it easier to evacuate. Public facilities or village land were chosen as evacuation sites. The chosen place already meets criteria such as the capacity to meet capacity, a location easily

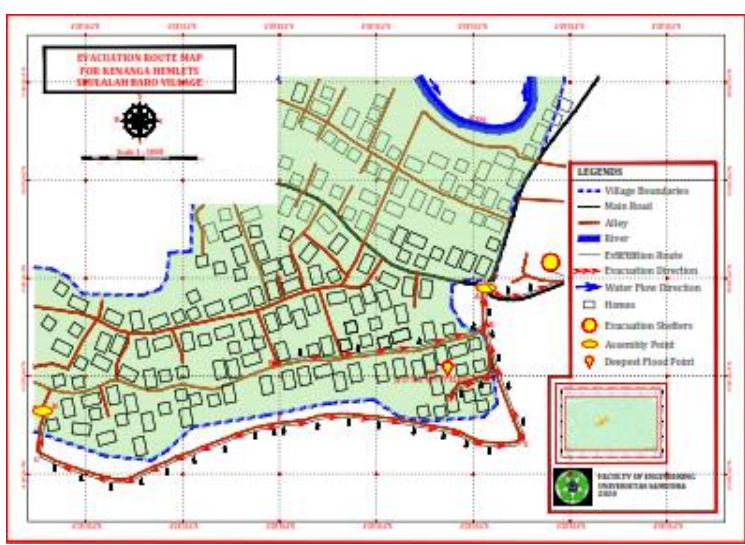

Fig. 8. Evacuation route map for Kenanga Hamlet in Seulalah Baru Village

accessible by refugees, an available public kitchen, and MCK. Evacuation routes are made in the direction of avoiding flood areas that have a higher depth, this is to make it easier for the community to evacuate independently and make it easier for SAR teams to help the community.

\section{CONCLUSIONS}

Based on the flood hazard level zoning map, it is known that the seven hamlets are flood hazard areas with high vulnerability levels. The flood hazard level is divided into four levels of vulnerability namely high, medium, low, and safe. The map of the evacuation route is made based on the direction of the water flow, the height of the floodwater level, the distance to the assembly point/evacuation shelters, and the height of the elevation of the soil. Selection of evacuation sites based on land height, ease of access, and availability of village land for evacuation. 


\section{ACKNOWLEDGMENTS}

This research is funded by LPPM and PM of Universitas Samudra, contract number 517/UN54.6/PG/2020.

\section{REFERENCES}

[1] S. Harsini, “Aplikasi Sistem Informasi Geografis Untuk Penentuan Jalur Evakuasi Bencana Banjir Luapan Sungai Bengawan Solo Di Kota Surakarta." Universitas Muhammadiyah Surakarta, 2014.

[2] Undang-undang Republik Indonesia, No. 24 Tahun 2007 tentang Penanggulangan. Lembaran Negara RI Tahun 2007, 2007.

[3] P.S. Atmodjo, S. Sangkawati, and A.B. Setiaji, "Analisis Efektivitas Jalur Evakuasi Bencana Banjir,” MEDIA Komun. Tek. SIPIL, vol. 21, no. 1 , pp. 23-34.
[4] T. Lakshay, A. Agarwal, and N.B. Bolia, "Route Guidance Map for Emergency Evacuation," 2016.

[5] N. Husa and A. Damayanti, "Evacuation Route and Evacuation Shelter Planning for Tsunami Hazard in Pangandaran District," in IOP Conference Series: Earth and Environmental Science, 2019, vol. 311, no. 1, p. 12023.

[6] D. Yusuf, "Flood Points Distribution Mapping for the Determination of Evacuation Routes and Disaster Posts in Gorontalo City," in IOP Conference Series: Earth and Environmental Science, 2020, vol. 589, no. 1, p. 12004

[7] S. Effendi, “Tukiran. 2012. Metode Penelitian Survei," Jakarta LP3S

[8] N. Nuryanti, J.L. Tanesib, and A. Warsito, "Pemetaan Daerah Rawan Banjir Dengan Penginderaan Jauh Dan Sistem Informasi Geografis Di Kecamatan Kupang Timur Kabupaten Kupang Provinsi Nusa Tenggara Timur,” J. Fis. Fis. Sains dan Apl., vol. 3, no. 1, pp. 73-79, 2018 